\title{
Radioactive Instillation
}

National Cancer Institute

\section{Source}

National Cancer Institute. Radioactive Instillation. NCI Thesaurus. Code C84370.

Implantation of radioactive material in an internal anatomic site. 